\title{
Preparation of $\mathrm{Si}_{2} \mathrm{~N}_{2} \mathrm{O}$ from Flashing Combustion Synthesized $\mathrm{Si}_{3} \mathrm{~N}_{4}$ and Silica Fume
}

\author{
B. $\mathrm{Li}^{1}$, J.H. Chen ${ }^{1 *}, \mathrm{M}$. W. Yan ${ }^{1}$, X.P. $\mathrm{Li}^{1}$, J.L. $\operatorname{Sun}^{1} \&$ Y. $\mathrm{Li}^{1}, \mathrm{M} . \mathrm{Wei}^{2}$ \\ ${ }^{1}$ School of Materials Science Engineering, University of Science and Technology Beijing, Beijing, \\ P.R.China \\ ${ }^{2}$ Shanxi Jiangyang Chemical Co.,Ltd., Taiyuan, P.R.China
}

Keyword: Silica fume; $\mathrm{Si}_{2} \mathrm{~N}_{2} \mathrm{O}$; Flashing combustion synthesis; Melting liquid

\begin{abstract}
Using flashing combustion synthesized $\mathrm{Si}_{3} \mathrm{~N}_{4}$ and silica fume as raw materials, the effects of firing temperature $\left(1300^{\circ} \mathrm{C}, 1400^{\circ} \mathrm{C}, 1500^{\circ} \mathrm{C}\right.$, and $\left.1600^{\circ} \mathrm{C}\right)$ and duration $(3 \mathrm{~h}, 6 \mathrm{~h}$, and $9 \mathrm{~h}$ ) on the synthesis of $\mathrm{Si}_{2} \mathrm{~N}_{2} \mathrm{O}$ were studied. The results show that the main mechanism of the reaction is $\mathrm{Si}_{3} \mathrm{~N}_{4}$ and silica fume react to form $\mathrm{Si}_{2} \mathrm{~N}_{2} \mathrm{O}$ through solid-solid reaction or solid-liquid reaction. After heat treatment at $1300^{\circ} \mathrm{C}$, there is a small amount of melting liquid in the system, with a trace of $\mathrm{Si}_{2} \mathrm{~N}_{2} \mathrm{O}$ formed. After heat treatment at $1400^{\circ} \mathrm{C}, 1500^{\circ} \mathrm{C}$, and $1600^{\circ} \mathrm{C}$, there is a large amount of melting liquid in the system, accelerating the formation of $\mathrm{Si}_{2} \mathrm{~N}_{2} \mathrm{O}$ slightly. The duration has very little effect on the synthesis reaction. When $\mathrm{Si}_{2} \mathrm{~N}_{2} \mathrm{O}$ forms, the oxygen content in the melting liquid decreases, viscosity of the liquid increases, the diffusion of ions in the melting liquid slows, hindering the continuous crystallization of $\mathrm{Si}_{2} \mathrm{~N}_{2} \mathrm{O}$. Thus, a fusing agent or hot pressing is re-quired to introduce more low viscosity liquid for the continuous crystallization of $\mathrm{Si}_{2} \mathrm{~N}_{2} \mathrm{O}$. In addition, silica fume crystallizes obviously at $1300^{\circ} \mathrm{C}$ and $1400^{\circ} \mathrm{C}$.
\end{abstract}

\section{Introduction}

$\mathrm{Si}_{2} \mathrm{~N}_{2} \mathrm{O}$ is a ceramic material with high refractoriness featured with high thermodynamic stable temperature $^{[7]}$, excellent thermal shock resistance ${ }^{[9]}$, good oxidation resistance, high hot strength, and good resistance to nonferrous metals melts ${ }^{[1]}$, etc. Compared with $\mathrm{Si}_{3} \mathrm{~N}_{4}$ ceramics it has better oxidation resistance at elevated temperatures, i.e. good oxidation resistance at $1600^{\circ} \mathrm{C}$ in air and high modulus of rupture at $1400^{\circ} \mathrm{C}^{[6]}$. Therefore, $\mathrm{Si}_{2} \mathrm{~N}_{2} \mathrm{O}$ is a promising high temperature structural material used in high temperature oxidization condition.

$\mathrm{Si}_{2} \mathrm{~N}_{2} \mathrm{O}$ can be obtained by two approaches. The first one, use metal silicon and $\mathrm{SiO}_{2}$ as starting materials, utilize the heat released by the SHS process to synthesize $\mathrm{Si}_{2} \mathrm{~N}_{2} \mathrm{O}$ in nitrogen atmosphere at high temperatures ${ }^{[10]}$. The second one, use $\mathrm{SiO}_{2}$ and $\mathrm{Si}_{3} \mathrm{~N}_{4}$ as the starting materials to synthesize $\mathrm{Si}_{2} \mathrm{~N}_{2} \mathrm{O}^{[8]}$. $\mathrm{Si}_{2} \mathrm{~N}_{2} \mathrm{O}$ mainly forms from nitrogen containing liquid ${ }^{[3]}$. In the second approach, the suitable liquid to produce $\mathrm{Si}_{2} \mathrm{~N}_{2} \mathrm{O}$ is the key point. What's more, the reaction rate is very low. Thus, the preparation of $\mathrm{Si}_{2} \mathrm{~N}_{2} \mathrm{O}$ in China mainly adopts the first one and most of them are in lab-scale.

The efficiency of synthesis $\mathrm{Si}_{2} \mathrm{~N}_{2} \mathrm{O}$ from metal silicon is high, but the synthesis is directly influenced by factors such as the diffusion depth of nitrogen in the reaction system and the diffusion efficiency. In addition, the structure of the as-prepared products is hard to control. So this method is more suitable to synthesize $\mathrm{Si}_{2} \mathrm{~N}_{2} \mathrm{O}$ raw material. The preparation of $\mathrm{Si}_{2} \mathrm{~N}_{2} \mathrm{O}$ products requires methods such as hot pressed sintering based on the pre-synthesized starting materials ${ }^{[4]}$.

As for the mass produced large sized products such as refractories, the SHS process of metal silicon greatly restrains the production of $\mathrm{Si}_{2} \mathrm{~N}_{2} \mathrm{O}$-related refractories. Take the penetration depth of nitrogen into the product bodies for example, commonly, the penetration depth of nitrogen in refractories is $3-4 \mathrm{~cm}$, too shallow for the blocks with thickness of dozens of centimeters. Besides, the process shall proceed in conditions of high temperature, high pressure and nitrogen atmosphere, which is hard to realize the industrialization.

Thus, in this work, $\mathrm{Si}_{2} \mathrm{~N}_{2} \mathrm{O}$ was prepared with silica fume and $\mathrm{Si}_{3} \mathrm{~N}_{4}$ as raw materials sintered under normal pressure in hot carbon reduced air atmosphere, which is easy to industrialize. The silica fume was from the ferroalloy industry and has a high specific surface area and a high activity. 
The $\mathrm{Si}_{3} \mathrm{~N}_{4}$ was prepared by flashing combustion method. The feasibility to industrialize this simple process was discussed. The effects of reaction temperature and duration on the synthesis of $\mathrm{Si}_{2} \mathrm{~N}_{2} \mathrm{O}$ from silica fume and $\mathrm{Si}_{3} \mathrm{~N}_{4}$ were studied.

\section{Experiment}

The flashing combustion synthesized $\beta-\mathrm{Si}_{3} \mathrm{~N}_{4}$ fines with $d_{50}$ of $45 \mu \mathrm{m}$, and the silica fume with a $\mathrm{SiO}_{2}$ content over $90 \%$ and $d_{50}$ of $0.85 \mu \mathrm{m}$ were adopted as the raw materials. Mixture with a $\mathrm{Si}_{3} \mathrm{~N}_{4}: \mathrm{SiO}_{2}$ mass ratio of $50 \%: 50 \%$ was ball mixed in a ball mill for 4 h, adding with $0.2 \%$ sodium hexametahposphate. After drying, the ball-milled mixture was added with a temporary binder and pressed into specimens with sizes of $\Phi 25 \times 20 \mathrm{~mm}$ under $6 \mathrm{MPa}$.

As seen in the S-C-N-O system state diagram (Fig. 1), the dashed line corresponds to the hot carbon reduced air atmosphere. It is found that the stable phase at the temperature range of 1250$1700^{\circ} \mathrm{C}$ is $\mathrm{Si}_{2} \mathrm{~N}_{2} \mathrm{O}$, indicating this atmosphere is favorable to the formation of $\mathrm{Si}_{2} \mathrm{~N}_{2} \mathrm{O}$.

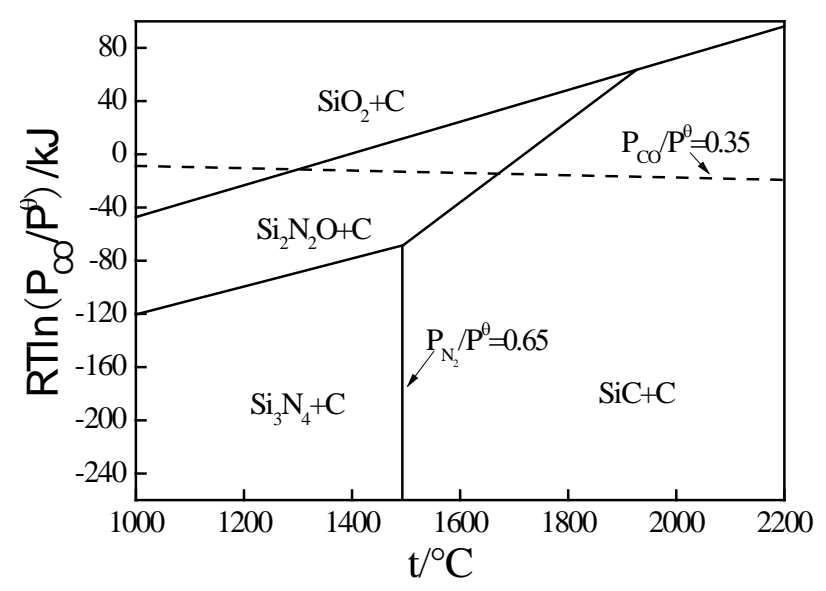

Figure 1. State diagram of S-C-N-O system

This work adopted the hot carbon reduced air atmosphere mentioned in Fig. 1. Blow the air slowly into a high temperature atmosphere furnace through a hot carbon net of $1500^{\circ} \mathrm{C}$. Then, raise the temperature slowly to $1300^{\circ} \mathrm{C}, 1400^{\circ} \mathrm{C}, 1500^{\circ} \mathrm{C}$, and $1600^{\circ} \mathrm{C}$ for duration of $3 \mathrm{~h}$, $6 \mathrm{~h}$, and $9 \mathrm{~h}$, respectively. Sample from the inside of the specimen and analyze with XRD (X' pert PRO MPD, Philips, Netherlands), SEM (FEI Nova 230 Nano SEM, FEI Company, USA), and EDS (Inca Energy, Oxford, UK) to investigate the phase composition, microstructure, and element distribution of the specimens.

\section{Results and discussion}

\subsection{Experiment results}

(1)SEM analysis of raw materials

As can be seen in Fig. 2(a), the particles of silica fume from the ferroalloys industry are small, ranging from dozens to hundreds of nanometers. The flashing combustion synthesized silica nitride particles develop well with prismatic shapes. And the crystals interlock with each other with diameters of micrometers and length of dozens of micrometers. 

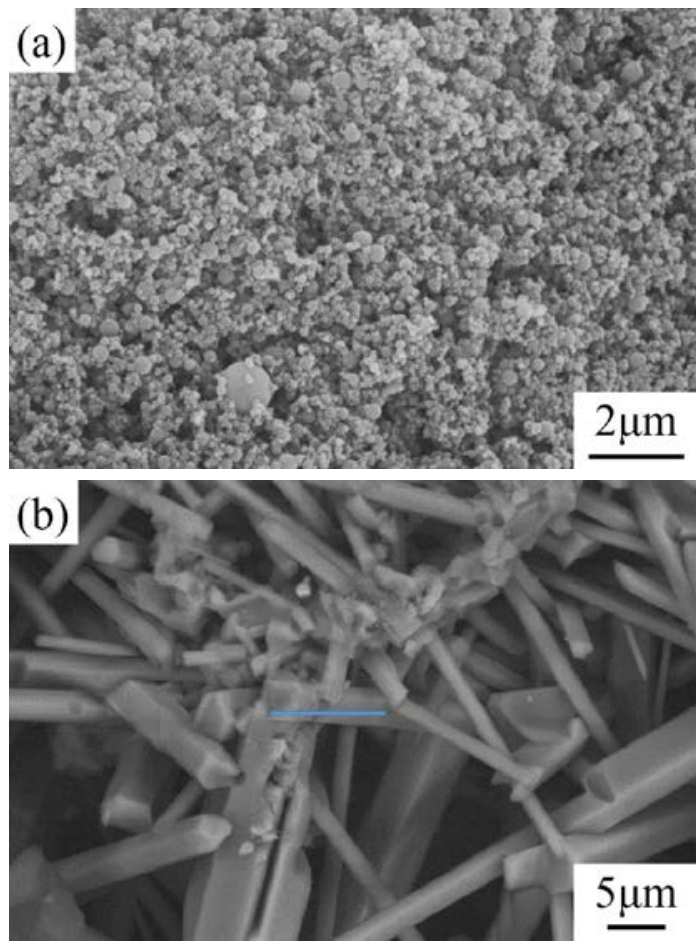

Figure 2. SEM photographs of silica fume and flashing combustion synthesized $\beta-\mathrm{Si}_{3} \mathrm{~N}_{4}$ :(a) silica fume, (b) $\beta-\mathrm{Si}_{3} \mathrm{~N}_{4}$.

(2)Analysis of specimens with different firing temperatures and different duration

(1) XRD analysis of specimens fired at $1300^{\circ} \mathrm{C}, 1400^{\circ} \mathrm{C}, 1500^{\circ} \mathrm{C}$ and $1600^{\circ} \mathrm{C}$ for $3 \mathrm{~h}$

As shown in Fig. 3, after firing at $1300^{\circ} \mathrm{C}$, the peaks of $\mathrm{Si}_{2} \mathrm{~N}_{2} \mathrm{O}$ are observed, indicating that $\mathrm{Si}_{2} \mathrm{~N}_{2} \mathrm{O}$ forms at this temperature. As firing temperature rises, the peaks get stronger. After firing at $1600^{\circ} \mathrm{C}$, the peaks of $\mathrm{Si}_{2} \mathrm{~N}_{2} \mathrm{O}$ are very obvious. But in general, with the duration of $3 \mathrm{~h}$, the effect of firing temperature on the peaks is not obvious: the peak intensity gets stronger mildly as temperature rises. $\beta-\mathrm{Si}_{3} \mathrm{~N}_{4}$ is still the main phase, meanwhile, $\mathrm{SiO}_{2}$ is also a main phase, and the peaks of $\mathrm{SiO}_{2}$ tend to be stronger at $1300 \sim 1400^{\circ} \mathrm{C}$, after $1500^{\circ} \mathrm{C}$ the $\mathrm{SiO}_{2}$ peaks weaken greatly, which means that the silica fume crystallizes intensely at $1300-1400^{\circ} \mathrm{C}$. After $1500^{\circ} \mathrm{C}$, the peaks get lower, and amorphous peaks appear at low angles in XRD patterns.

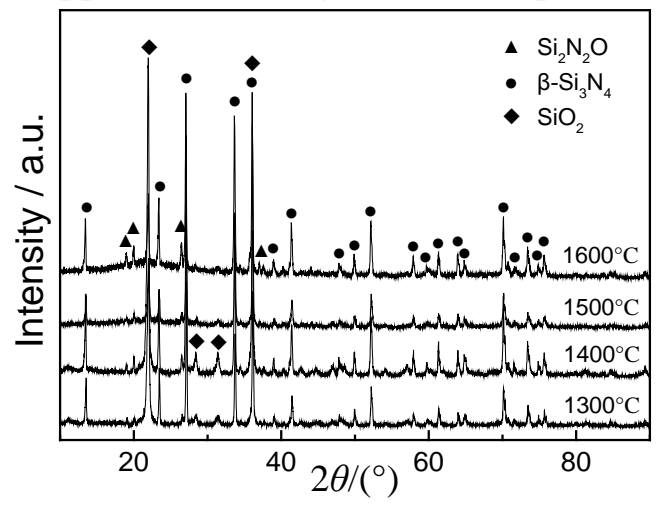

Figure 3. XRD patterns of specimens fired at $1300^{\circ} \mathrm{C}, 1400^{\circ} \mathrm{C}, 1500^{\circ} \mathrm{C}$ and $1600^{\circ} \mathrm{C}$ for $3 \mathrm{~h}$

(2) XRD analysis of specimens fired at $1300^{\circ} \mathrm{C}, 1400^{\circ} \mathrm{C}, 1500^{\circ} \mathrm{C}$ and $1600^{\circ} \mathrm{C}$ for $3 \mathrm{~h}, 6 \mathrm{~h}$ and $9 \mathrm{~h}$, respectively

As shown in Fig. 4, at firing temperature of $1300^{\circ} \mathrm{C}$, the duration of $3 \mathrm{~h}, 6 \mathrm{~h}$, 9h has no obvious influence on the peak intensity of $\mathrm{Si}_{2} \mathrm{~N}_{2} \mathrm{O}$. The peak intensities at firing temperature of $1400^{\circ} \mathrm{C}$, $1500^{\circ} \mathrm{C}$ and $1600^{\circ} \mathrm{C}$ are stronger than that at $1300^{\circ} \mathrm{C}$. However, at different temperatures, the duration has no influence on the crystallization of the $\mathrm{Si}_{2} \mathrm{~N}_{2} \mathrm{O}$. It is noted that the system has strong 
$\mathrm{SiO}_{2}$ peaks at $1300^{\circ} \mathrm{C}$ and $1400^{\circ} \mathrm{C}$, which means that the crystallization force of the silica fume is very strong at the temperatures. At $1500^{\circ} \mathrm{C}$ and $1600^{\circ} \mathrm{C}$, the peak intensity of $\mathrm{SiO}_{2}$ decreases greatly and the XRD results show the appearance of amorphous phases, indicating that silica fume is in melting state. Peak intensity of $\beta-\mathrm{Si}_{3} \mathrm{~N}_{4}$ varies slightly at different tempeartures, meaning that the content of $\beta-\mathrm{Si}_{3} \mathrm{~N}_{4}$ merely changes and proving it is stable in the system.
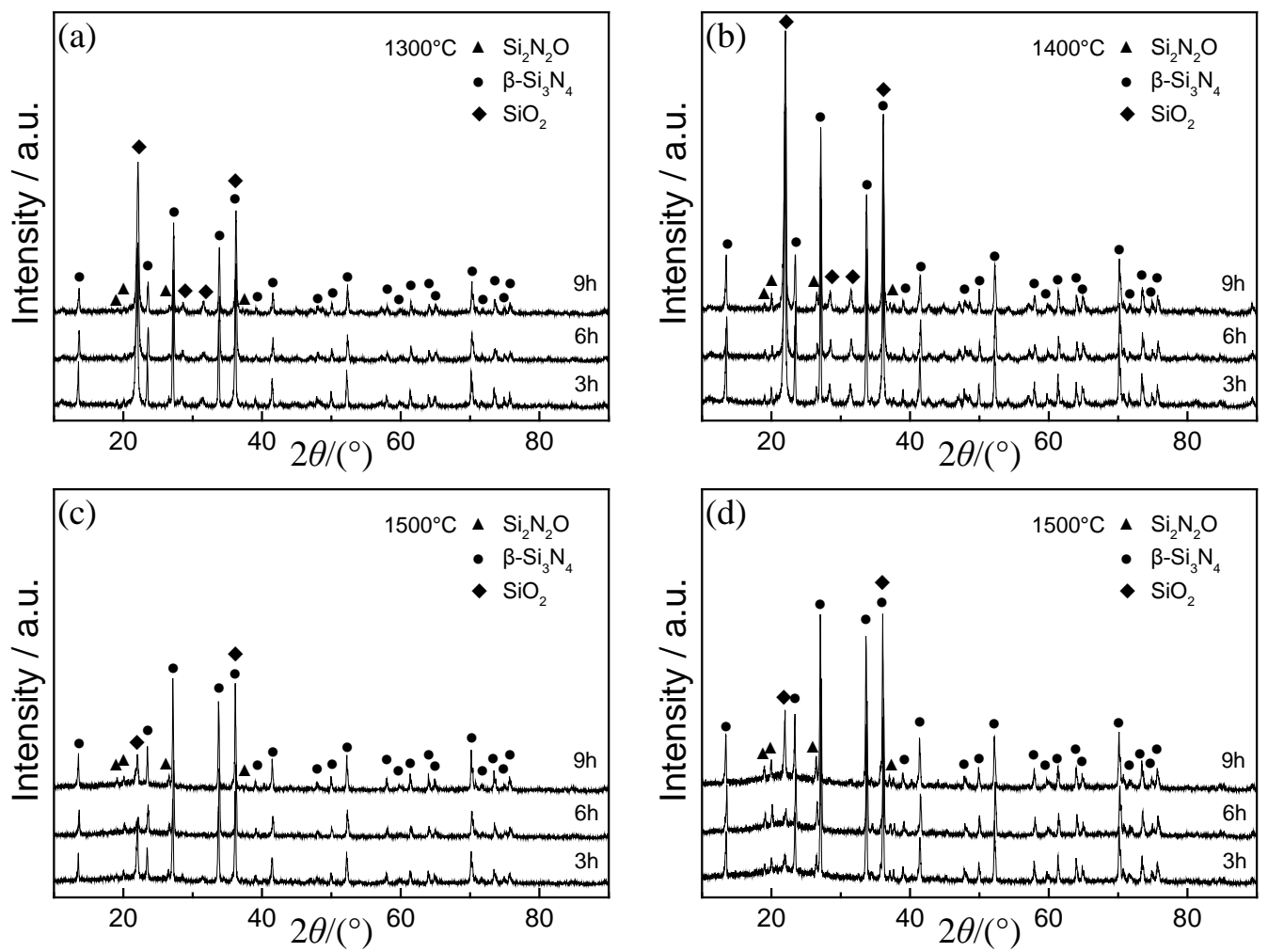

Fig. 4 XRD pattern of specimens fired at different sintering temperatures for different duration: (a) $1300^{\circ} \mathrm{C}$; (b) $1400^{\circ} \mathrm{C}$; (c) $1500^{\circ} \mathrm{C}$; (d) $1600^{\circ} \mathrm{C}$.

(3)SEM analysis of specimens fired at different temperatures for $6 \mathrm{~h}$

SEM photographs of specimens fired at different temperatures for $6 \mathrm{~h}$ are shown in Fig.5. Combined with the XRD results, it is concluded that at $1300^{\circ} \mathrm{C}$, only a small amount of melting phase forms in the system, and the $\mathrm{Si}_{2} \mathrm{~N}_{2} \mathrm{O}$ formation is very little. Since there are some impurities existing in silica fume, a trace of melting liquid forms, resulting in some local closure and separation in the system. At $1300^{\circ} \mathrm{C}$, most $\mathrm{Si}_{3} \mathrm{~N}_{4}$ particles are loose and insolated. Small and uniform pores distributes among the particles. At $1400^{\circ} \mathrm{C}$, the $\mathrm{Si}_{3} \mathrm{~N}_{4}$ particles are still insolated, but some liquid phases appear in the system. Although the bonding is not strong, obvious packing and cementation exist. At $1500^{\circ} \mathrm{C}$ and $1600^{\circ} \mathrm{C}$, the system is almost in melting state, with a totally closed state. Most $\mathrm{Si}_{3} \mathrm{~N}_{4}$ particles are bonded together, few $\mathrm{Si}_{3} \mathrm{~N}_{4}$ particles are insolated. Melting phases pack the $\mathrm{Si}_{3} \mathrm{~N}_{4}$ particles tightly. With tempreture increasing, the pores are becoming more and more and the pore volume increases. The whole system presents a cemented network structure. 

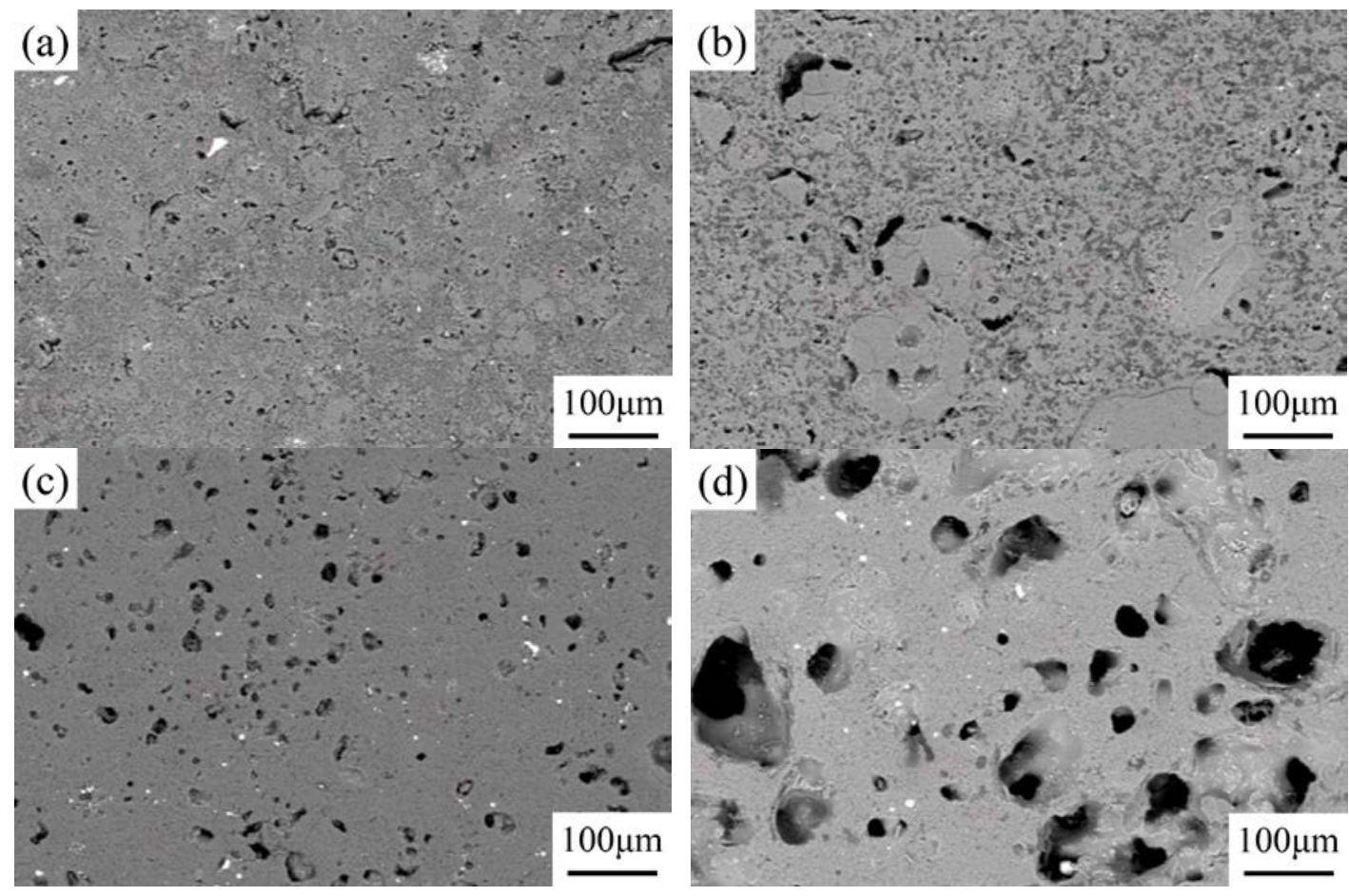

Figure 5. SEM photographs of specimens fired at different sintering temperatures for $6 \mathrm{~h}$ (a) $1300^{\circ} \mathrm{C}$; (b) $1400^{\circ} \mathrm{C}$; (c) $1500^{\circ} \mathrm{C}$; (d) 1600

\subsection{Analysis and discussion}

(1) Thermodynamics analysis of $\mathrm{Si}_{3} \mathrm{~N}_{4}$ - silica fume system

In this system, the formed $\mathrm{Si}_{2} \mathrm{~N}_{2} \mathrm{O}$ is mainly from the following reactions.

$$
\begin{aligned}
& \mathrm{Si}_{3} \mathrm{~N}_{4}(\mathrm{~s})+\frac{3}{2} \mathrm{CO}(\mathrm{g})=\frac{3}{2} \mathrm{Si}_{2} \mathrm{~N}_{2} \mathrm{O}+\frac{1}{2} \mathrm{~N}_{2}+\frac{3}{2} \mathrm{C} \\
& \Delta_{\mathrm{r}} G^{\theta}=-381420.75+159.50 T\left(\mathrm{~J} \cdot \mathrm{mol}^{-1}\right) \\
& \mathrm{Si}_{3} \mathrm{~N}_{4}(\mathrm{~s})+\frac{3}{4} \mathrm{O}_{2}(\mathrm{~g})=\frac{3}{2} \mathrm{Si}_{2} \mathrm{~N}_{2} \mathrm{O}+\frac{1}{2} \mathrm{~N}_{2}(\mathrm{~g}) \\
& \Delta_{\mathrm{r}} G^{\theta}=-553023.50+30.85 T\left(\mathrm{~J} \cdot \mathrm{mol}^{-1}\right) \\
& \mathrm{Si}_{3} \mathrm{~N}_{4}(\mathrm{~s})+\mathrm{SiO}_{2}(\mathrm{~s})=2 \mathrm{Si}_{2} \mathrm{~N}_{2} \mathrm{O}(\mathrm{s}) \\
& \Delta_{\mathrm{r}} G^{\theta}=-178770.00+31.10 T\left(\mathrm{~J} \cdot \mathrm{mol}^{-1}\right)
\end{aligned}
$$

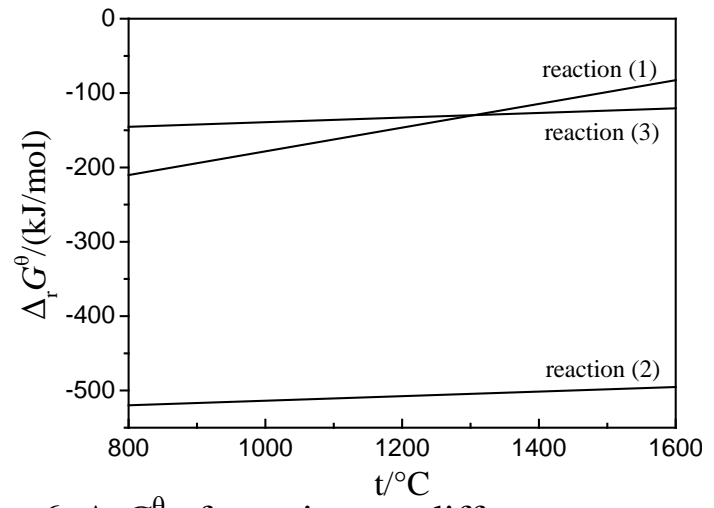

Figure 6. $\Delta_{\mathrm{r}} G^{\theta}$ of reactions at different temperatures

As shown in Fig. 6, in normal conditions, reactions (1)-(3) can happen. Reaction (2) has the lowest $\Delta_{\mathrm{r}} G^{\theta}$, making it the easiest one to happen. However, after $1400^{\circ} \mathrm{C}$, the impurities in the silica fume form phases with low melting temperatures, blocking the pores and hindering the penetration of $\mathrm{O}_{2}$ and $\mathrm{CO}$, making the gas reactions hard to proceed in the system. Thus, the formation of 
$\mathrm{Si}_{2} \mathrm{~N}_{2} \mathrm{O}$ at different temperatures is based on the reaction between $\mathrm{Si}_{3} \mathrm{~N}_{4}$ and silica fume. Reactions (1) and (2) are restrained in this system, therefore, the forming speed of $\mathrm{Si}_{2} \mathrm{~N}_{2} \mathrm{O}$ depends on the speed of solid-solid reactions or solid-liquid reactions ${ }^{[2]}$.

As shown in Fig. 6, in normal conditions, reactions (1)-(3) can happen. Reaction (2) has the lowest $\Delta_{\mathrm{r}} G^{\theta}$, making it the easiest one to happen. However, after $1400^{\circ} \mathrm{C}$, the impurities in the silica fume form phases with low melting temperatures, blocking the pores and hindering the penetration of $\mathrm{O}_{2}$ and $\mathrm{CO}$, making the gas reactions hard to proceed in the system. Thus, the formation of $\mathrm{Si}_{2} \mathrm{~N}_{2} \mathrm{O}$ at different temperatures is based on the reaction between $\mathrm{Si}_{3} \mathrm{~N}_{4}$ and silica fume. Reactions (1) and (2) are restrained in this system, therefore, the forming speed of $\mathrm{Si}_{2} \mathrm{~N}_{2} \mathrm{O}$ depends on the speed of solid-solid reactions or solid-liquid reactions ${ }^{[2]}$.

(2) Effect of temperature on $\mathrm{Si}_{2} \mathrm{~N}_{2} \mathrm{O}$ crystallization

Diffusion between solid $\mathrm{SiO}_{2}$ and $\mathrm{Si}_{3} \mathrm{~N}_{4}$ is slow. If only relying on the contact diffusion between the two solids, there will be only very a small amount of $\mathrm{Si}_{2} \mathrm{~N}_{2} \mathrm{O}$ forming. The growth of $\mathrm{Si}_{2} \mathrm{~N}_{2} \mathrm{O}$ crystals just likes the synthesis of Sialon: as the appearance of liquid, $\mathrm{Si}_{2} \mathrm{~N}_{2} \mathrm{O}$ crystallizes from the liquid, and grows bigger. So the liquid in the system is a key factor to make the $\mathrm{Si}_{2} \mathrm{~N}_{2} \mathrm{O}$ crystals nucleate and grow. Therefore, a large amount of Si-N-O-X silicate melting phase is the necessary condition to form $\mathrm{Si}_{2} \mathrm{~N}_{2} \mathrm{O}$.

After firing at $1300^{\circ} \mathrm{C}$, only a trace of melting liquid forms in the system (Fig. 5(a)), $\mathrm{Si}_{2} \mathrm{~N}_{2} \mathrm{O}$ can only be formed by the diffusion or through the very limited liquid, so very little $\mathrm{Si}_{2} \mathrm{~N}_{2} \mathrm{O}$ forms. As temperature rises, the liquid is becoming more and more: liquid is not obvious at $1300^{\circ} \mathrm{C}$, but obvious at $1400^{\circ} \mathrm{C}$; at $1500^{\circ} \mathrm{C}$ and $1600^{\circ} \mathrm{C}$, the system melts completely. However, as temperature increases, the $\mathrm{Si}_{2} \mathrm{~N}_{2} \mathrm{O}$ peaks tend to be obvious, but the increase is slight, and there is no large amount of $\mathrm{Si}_{2} \mathrm{~N}_{2} \mathrm{O}$ formed. The increase of temperature enhances the liquid content of the system but only slightly improves the crystallization of $\mathrm{Si}_{2} \mathrm{~N}_{2} \mathrm{O}$.

(3) Effect of duration on $\mathrm{Si}_{2} \mathrm{~N}_{2} \mathrm{O}$ crystallization

The XRD patterns of specimens fired at one temperature for different duration (Fig. 4) show that at $1300^{\circ} \mathrm{C}, 1400^{\circ} \mathrm{C}, 1500^{\circ} \mathrm{C}$, and $1600^{\circ} \mathrm{C}$, with duration increasing from $3 \mathrm{~h}$ to $9 \mathrm{~h}$, the diffraction peaks of $\mathrm{Si}_{2} \mathrm{~N}_{2} \mathrm{O}$ do not increase obviously, indicating the system does not have a large amount of $\mathrm{Si}_{2} \mathrm{~N}_{2} \mathrm{O}$ formed. At $1500^{\circ} \mathrm{C}$ and $1600^{\circ} \mathrm{C}$, the melting liquid content in the system is relatively high. In this condition, prolonging the duration has no accelerating effect on $\mathrm{Si}_{2} \mathrm{~N}_{2} \mathrm{O}$ crystallization.

(4) Analysis on $\mathrm{Si}_{2} \mathrm{~N}_{2} \mathrm{O}$ crystallization mechanism in $\mathrm{Si}_{3} \mathrm{~N}_{4}$ - silica fume system

At $1300^{\circ} \mathrm{C}$ and $1400^{\circ} \mathrm{C}$, strong silica fume crystallization appears in the system. The structure of short-range order and long-range disorder has turned into long-range order structure. Some Si-Si and $\mathrm{O}-\mathrm{O}$ bonds break, forming a stable tetrahedral structure with $\mathrm{Si}-\mathrm{O}$ bonds. At $1500^{\circ} \mathrm{C}$ and $1600^{\circ} \mathrm{C}$, silica fume melts, providing the precursor for the growth of $\mathrm{Si}_{2} \mathrm{~N}_{2} \mathrm{O}$ crystals.

When solid or melting $\mathrm{SiO}_{2}$ contacts with the surface of $\mathrm{Si}_{3} \mathrm{~N}_{4}$ crystals, some [Si-N] tetrahedrons or groups leave the surface of $\mathrm{Si}_{3} \mathrm{~N}_{4}$ crystals and diffuse into the melt. [Si-N] tetrahedrons or groups react with $\mathrm{O}^{2-}$ or [ $\mathrm{Si}-\mathrm{O}$ ] tetrahedrons from the melt, breaking $\mathrm{Si}-\mathrm{N}$ bonds and establishing new $\mathrm{Si}-\mathrm{O}$ bonds, so $\mathrm{Si}_{2} \mathrm{~N}_{2} \mathrm{O}$ crystallizes. Once $\mathrm{Si}_{2} \mathrm{~N}_{2} \mathrm{O}$ crystals form, the oxygen content in the melt declines and the liquid viscosity increases, making ions in the melt hard to diffuse and thus hindering the continuous crystallization of $\mathrm{Si}_{2} \mathrm{~N}_{2} \mathrm{O}$, Therefore, for the continuous crystallization of $\mathrm{Si}_{2} \mathrm{~N}_{2} \mathrm{O}$, a fusing agent or hot pressing is required ${ }^{[1,5]}$, because this will introduce more low viscosity liquid for the mass crystallization of $\mathrm{Si}_{2} \mathrm{~N}_{2} \mathrm{O}$.

\section{Conclusions}

(1) In reduction atmosphere, $\mathrm{Si}_{2} \mathrm{~N}_{2} \mathrm{O}$ was synthesized using flashing combustion synthesized $\mathrm{Si}_{3} \mathrm{~N}_{4}$ and silica fume as raw materials. Because of the self-close effect of silica fume, the $\mathrm{Si}_{2} \mathrm{~N}_{2} \mathrm{O}$ phase is the direct reaction product of $\mathrm{Si}_{3} \mathrm{~N}_{4}$ and silica fume.

(2) After heat treatment at $1300^{\circ} \mathrm{C}$, there is a small amount of melting liquid in the system, with a trace $\mathrm{Si}_{2} \mathrm{~N}_{2} \mathrm{O}$ formed. After heat treatment at $1400^{\circ} \mathrm{C}, 1500^{\circ} \mathrm{C}$, and $1600^{\circ} \mathrm{C}$, there is a large amount of melting liquid in the system, accelerating the formation of $\mathrm{Si}_{2} \mathrm{~N}_{2} \mathrm{O}$ slightly. The temperature 
rising can enhance the melt content of the system, but only slightly improves the $\mathrm{Si}_{2} \mathrm{~N}_{2} \mathrm{O}$ crystallization. The prolonging of duration has very little effect on the $\mathrm{Si}_{2} \mathrm{~N}_{2} \mathrm{O}$ crystallization.

(3) The system show strong silica fume crystallization at $1300^{\circ} \mathrm{C}$ and $1400^{\circ} \mathrm{C}$. At $1500^{\circ} \mathrm{C}$ and $1600^{\circ} \mathrm{C}$, the silica fume is melting and amorphous.

(4) When $\mathrm{Si}_{2} \mathrm{~N}_{2} \mathrm{O}$ crystals form, the oxygen content in the melting liquid decreases, liquid viscosity increases as well, so the diffusion of ions in the melt becomes difficult, hindering the continuous crystallization of $\mathrm{Si}_{2} \mathrm{~N}_{2} \mathrm{O}$. Thus, fusing agent or hot press is required to introduce more low viscosity liquid for the continuous crystallization of $\mathrm{Si}_{2} \mathrm{~N}_{2} \mathrm{O}$.

\section{Acknowledgments}

This research was supported by the National Science-technology Support Plan Projects (Grant No.2013BAF09B01). The authors also wish to gratefully acknowledge the technical assistance of Prof. J.H. Chen who is the corresponding author of this article at the University of Science and Technology Beijing, Beijing.

\section{References}

[1] Xiao H.N. \& Gao P.Z. 2006. High performance structure ceramics and application. Beijing: Chemical Industry Press.

[2] Chen J.H. et al. 2007. High-temperature reaction of silica fume- $\mathrm{Si}_{3} \mathrm{~N}_{4}$ system. Refractories. 41(6): 427-429.

[3] Wu, S.J. \& Li, X.M. 2012. In-situ reactive synthesis of $\mathrm{Si}_{2} \mathrm{~N}_{2} \mathrm{O}$ ceramics and its properties. Metallurgical and Materials Transactions A. 43(12): 4859-4865.

[4] Qiao W. et al. 2012. Influence of silicon source to prepara-tion of reaction sintering silicon oxynitride, 17th national high technology ceramics academic annual meeting, Nanjing, Jiangsu, P. R. China.

[5] Dong $X$, et al. 2013. Microstructure characterization of in situ synthesized porous $\mathrm{Si}_{2} \mathrm{~N}_{2} \mathrm{O}$ ceramics using spodumene additive. Ceramics International. 39(4): 4657-4662.

[6] Radwan M. et al. 2003. New synthesis route for $\mathrm{Si}_{2} \mathrm{~N}_{2} \mathrm{O}$ ceramics based on desert sand. Journal of the European Ceramic Society. 23(13): 2337-2341.

[7] Xu X. et al. 2001. Pressureless sintering of $\mathrm{Si}_{2} \mathrm{~N}_{2}$ O. Journal of Inorganic Materials. 16(1): 165168.

[8] Fan L. \& Wang H.G. 2011. Research on preparation of $\mathrm{Si}_{2} \mathrm{~N}_{2} \mathrm{O}$ ceramic by nanometer amorphous silicon nitride, China (jingdezhen) high-tech ceramics international BBS and the 10th national engineering ceramics academic annual meeting, Jingdezhen Jiangxi, P. R. China.

[9] Li X.M. et al. 2013. Study on in-situ reaction synthesis and mechanical properties of $\mathrm{Si}_{2} \mathrm{~N}_{2} \mathrm{O}$ ceramic. Ceramics International. 39(3): 3035-3041.

[10] Li M.Q. 1978. Silicon oxynitride. ceramic, 1978(02): 20-23. 